\title{
Infeksi Cucumber mosaic virus dan Chilli veinal mottle virus pada Cabai di Kabupaten Rejang Lebong, Bengkulu
}

\section{Infection of Cucumber mosaic virus and Chilli veinal mottle virus on Chillipepper in Rejang Lebong Regency, Bengkulu}

\author{
Mimi Sutrawati*, Djamilah, Andreani Kinata \\ Universitas Bengkulu, Bengkulu 38371 A
}

\begin{abstract}
ABSTRAK
Penyakit mosaik yang disebabkan oleh Cucumber mosaic virus (CMV) dan Chilli veinal mottle virus (ChiVMV) merupakan penyakit utama pada pertanaman cabai dan dilaporkan sudah tersebar luas di Indonesia. Penelitian bertujuan untuk mengetahui sebaran dan infeksi CMV dan ChiVMV pada cabai di Kabupaten Rejang Lebong, Bengkulu serta mengidentifikasi serangga yang diduga berperan sebagai vektornya. Penelitian dilakukan dengan mengumpulkan sampel tanaman cabai yang bergejala maupun tidak bergejala yang diambil secara diagonal pada tiap petak pengamatan di sentra sayuran Kabupaten Rejang Lebong. Keberadaan CMV dan ChiVMV pada sampel diuji secara serologi dengan DAS-ELISA. Hasil deteksi menunjukkan adanya infeksi ganda CMV dan ChiVMV di 3 lokasi dengan kejadian penyakit 20-50\%. Kejadian infeksi ChiVMV (50-80\%) di kabupaten Rejang Lebong ternyata lebih tinggi daripada CMV (20-50\%), dan ditemukan di setiap lokasi survei. Serangga yang berhasil ditemukan di lokasi pengambilan sampel adalah Aphis gossypii.
\end{abstract}

Kata kunci: Aphis gossypii, CMV, ChiVMV, kejadian penyakit

\begin{abstract}
Mosaic disease caused by Cucumber mosaic virus (CMV) and Chilli veinal mottle Virus (ChiVMV) has been distributed widely in chilli in Indonesia and considered as important disease. A research was conducted to investigate the spread and incidence of CMV and ChiVMV in Rejang Lebong, Bengkulu and to identify its insect vector. Symptomatic and asymptomatic leaf samples were collected systematically from several chillipepper fields for further detection by DAS-ELISA (Double antibody sandwich-enzyme linked immunosorbant assay) using specific antibody for CMV and ChiVMV. The result showed that infection of both CMV and ChiVMV was found with disease incidence reached 20$50 \%$, whereas infection only by ChiVMV or CMV were $50-80 \%$ and $20-50 \%$, respectively. One species of aphid, i.e. Aphis gossypii was found from the fields.
\end{abstract}

Key words: Aphis gossypii, CMV, ChiVMV, disease incidence

\section{PENDAHULUAN}

Propinsi Bengkulu merupakan salah satu propinsi penghasil cabai merah di pulau Sumatera. Pada tahun 2009 produksi cabai di Bengkulu mencapai 47697 ton dengan produktivitas 5.69 ton/ha dan luas panen 8379 ha (BPS 2009). Kemampuan produksi cabai di Bengkulu masih tergolong rendah, seperti halnya produksi rata-rata nasional.

\footnotetext{
*Alamat penulis korespondensi: Jurusan Perlindungan Tanaman, Fakultas Pertanian, Universitas Bengkulu, Jalan WR Supratman Kandang Limun, Bengkulu 38371 A Tel: 073221170 ekst. 206, Surel: mimi_hpt37@yahoo.com
} 
Rata-rata produksi cabai di Indonesia hanya mencapai 5.5 ton/ha (Cropscience 2008), sedangkan potensi produksinya dapat mencapai 20 ton/ha (Duriat 1996).

Rendahnya produksi cabai secara nasional disebabkan oleh berkurangya luas panen. Selain itu, penyakit oleh infeksi virus merupakan salah satu kendala dalam produksi cabai. Gangguan yang disebabkan oleh infeksi virus dapat menyebabkan berkurangnya produktivitas tanaman baik dari segi jumlah maupun kualitas buah. Dilaporkan pula bahwa infeksi virus dapat memperpendek umur tanaman, meskipun sangat jarang menimbulkan kematian tanaman. Tanaman yang terinfeksi virus dapat meningkat sifat kerentanannya terhadap infeksi patogen lain dan serangan hama.

Taufik et al. (2005) melaporkan CMV dan ChiVMV merupakan virus utama pada tanaman cabai dan telah menyebar luas di berbagai daerah di Indonesia. Sutrawati (2012) melaporakan infeksi CMV di Kabupaten Rajang Lebong. Sudiono et al. (2005) melaporkan kejadian penyakit oleh Geminivirus di Bengkulu. Penelitian mengenai sebaran infeksi CMV dan ChiVMV dan kejadian penyakit kedua jenis virus ini menjadi penting untuk dilakukan mengingat kedua virus dapat menyebabkan kerugian bagi petani cabai. Infeksi ChiVMV dilaporkan dapat menyebabkan kehilangan hasil hingga 100\% (AVRDC 2003), sementara infeksi CMV menyebabkan nekrosis, shoestring, buah salah bentuk dan tanaman menjadi kerdil (Palukaitis etal.1992). Tanaman yangterserang CMV maupun ChiVMV dapat menjadi kerdil, bunga rontok sebelum pembuahan, sehingga dapat menyebabkan gagal panen.

Penularan dan penyebaran CMV dan ChiVMV antara lain ditentukan oleh aktivitas serangga vektornya, yaitu kutudaun. Lebih dari 60 spesies kutudaun dilaporkan dapat menularkan CMV secara non persisten, dua di antaranya ialah Myzus persicae dan Aphis gossypii (Agrios 2005). Serangga vektor ChiVMV diantaranya $A$. craccivora, A. gossypii, A. spiraecola, M. persicae, dan
Toxoptera citricidus menularkan secara non persisten (CABI 2005). Mengingat banyaknya spesies kutudaun yang dapat menularkan kedua virus tersebut, perlu dilakukan identifikasi serangga yang ada pada pertanaman cabai yang berpotensi sebagai vektor.

Penelitian ini bertujuan menentukan sebaran dan infeksi CMV dan ChiVMV di pertanaman cabai di Kabupaten Rejang Lebong, Bengkulu, serta mengidentifikasi serangga yang berpotensi sebagai vektornya.

\section{BAHAN DAN METODE}

\section{Pengamatan Gejala dan Pengambilan Sampel di Lapangan}

Lokasi tanaman cabai merah untuk pengambilan sampel terletak di Desa Air Meles Atas dan Mojorejo yang berada di Kabupaten Rejang Lebong, Bengkulu. Sampel di Desa Air Meles Atas diambil dari lahan dengan luas $1 / 4$ ha, sedangkan di Desa Mojorejo dari lahan dengan luas $3 / 4$ ha.

Pengamatan gejala infeksi virus dan pengambilan sampel tanaman cabai serta pengambilan serangga dilakukan pada 2 petak di Desa Air Meles Atas dan 3 petak di Desa Mojorejo, masing-masing petak berukuran $5 \mathrm{~m}$ x $5 \mathrm{~m}$. Pengambilan sampel tanaman cabai dilakukan dengan cara sistematis pada diagonal petak, sebanyak $10 \%$ populasi per petak pengamatan. Pengambilan serangga berupa kutudaun, baik nimfa maupun imago, dari tanaman sampel dilakukan secara langsung menggunakan kuas basah. Serangga yang diperoleh kemudian disimpan dalam tabung dengan penutup.

\section{Deteksi CMV dan ChiVMV}

Sampel tanaman cabai berupa daun muda tanaman cabai baik yang menunjukkan gejala terinfeksi virus maupun tidak bergejala dari lapangan dikirim ke Balai Penelitian Tanaman Hias, Segunung, Cianjur untuk deteksi virus. Metode deteksi virus dilakukan secara serologi dengan metode double antibody sandwich-enzyme linked immunosorbent assay (DAS-ELISA) dengan antiserum CMV dan 
ChiVMV. Hasil DAS-ELISA dianalisis secara kuantitatif menggunakan spektrofotometer dengan mengukur nilai absorban pada panjang gelombang $405 \mathrm{~nm}$. Sampel yang diuji dinyatakan positif terinfeksi virus jika memiliki nilai absorban dua kali nilai absorban kontrol negatif.

Kejadian penyakit dihitung berdasarkan hasil deteksi DAS-ELISA dengan rumus sebagai berikut:

$$
\mathrm{K}=\mathrm{n} / \mathrm{N} \times 100 \%
$$

dengan: $\mathrm{K}$, kejadian penyakit $\mathrm{CMV}$ atau ChiVMV; n, jumlah tanaman sampel yang positif terinfeksi CMV atau ChiVMV; N, jumlah total tanaman sampel.

\section{Identifikasi Serangga}

Serangga yang diperoleh dari lapangan diidentifikasi menggunakan mikroskop binokuler dengan kunci identifikasi serangga (Martin 1983; Godin dan Boivin 2002). Identifikasi dilakukan berdasarkan morfologi kutudaun dengan ciri pada sifunkuli, abdomen, bentuk dan warna kauda, dan jumlah rambut pada kauda.

\section{HASIL}

\section{Kondisi Pertanaman Cabai di Lokasi Pengambilan Sampel}

Kabupaten Rejang Lebong memiliki luas wilayah kurang lebih $4109.8 \mathrm{~km}^{2}$ dan populasi sekitar 250000 jiwa, dengan topografi wilayah yang berbukit-bukit. Kabupaten Rejang Lebong berada pada ketinggian kurang lebih $1200 \mathrm{~m}$ dpl dengan suhu rata-rata harian $26.5^{\circ} \mathrm{C}$.

Sistem budi daya yang digunakan petani Desa Air Meles Atas dan Mojorejo menggunakan mulsa plastik. Tanaman cabai merah cv. Lado di Desa Air Meles Atas ditanam secara tumpang sari dengan mentimun dan kubis, dan sebelumnya lahan tersebut ditanami mentimun. Pada saat pengambilan sampel, tanaman cabai berumur 100 hari dan baru 1 minggu disemprot dengan insektisida. Tanaman cabai di Desa Mojorejo berumur 90 hari dan ketika penelitian tanaman baru 2 hari disemprot insektisida, sedangkan pada petak ke-2 tanaman berumur 50 hari dan 1 hari disemprot insektisida. Tanaman cabai di Desa Mojorejo ini ditanam secara tumpang sari dengan tanaman tomat dan sebelumnya lahan ditanami bawang daun.

\section{Gejala Penyakit Akibat Infeksi Virus}

Pengamatan di lapangan menunjukkan gejala infeksi yang beragam, antara lain: mosaik pada daun muda dan penyempitan lamina daun (Gambar 1a); daun menguning sistemik dan kerdil (Gambar 1b) ; belang dan keriting pada daun muda (Gambar 1c); mosaik dan belang (Gambar 1d); belang hijau gelap di sekitar tulang daun (Gambar 1e); penyempitan tulang daun bahkan tidak terbentuk lamina daun sama sekali (Gambar 1f).

Berdasarkan gejala pada tanaman cabai dan hasil deteksi virus dengan DAS-ELISA, sampel tanaman cabai yang positif terinfeksi CMV menunjukkan gejala mosaik hijau kekuningan pada daun muda, serta penyempitan lamina daun. Tanaman yang positif terinfeksi ChiVMV menunjukkan gejala belang dengan permukaan daun menyempit sehingga seperti melepuh atau melengkung seperti mangkuk. Sampel tanaman cabai yang terinfeksi ganda oleh CMV dan ChiVMV menunjukkan belang dan malformasi daun yang lebih berat daripada sampel yang hanya terinfeksi CMV atau ChiVMV saja.

\section{Kejadian Penyakit CMV dan ChiVMV}

Infeksi CMV secara tunggal hanya terjadi pada 1 petak lokasi pengamatan dengan kejadian penyakit $20 \%$, sedangkan infeksi oleh ChiVMV secara tunggal ditemukan di semua lokasi pengamatan dengan kejadian penyakit yang tinggi, yaitu $50-80 \%$. Infeksi ganda CMV dan ChiVMV terjadi di 3 petak lokasi pengamatan dengan kejadian penyakit 20-50\%. Hal ini menunjukkan bahwa kejadian penyakit oleh infeksi ChiVMV di Kabupaten Rejang Lebong ternyata lebih tinggi daripada CMV yang ditemukan pada setiap petak lokasi pengamatan (Tabel 1). 

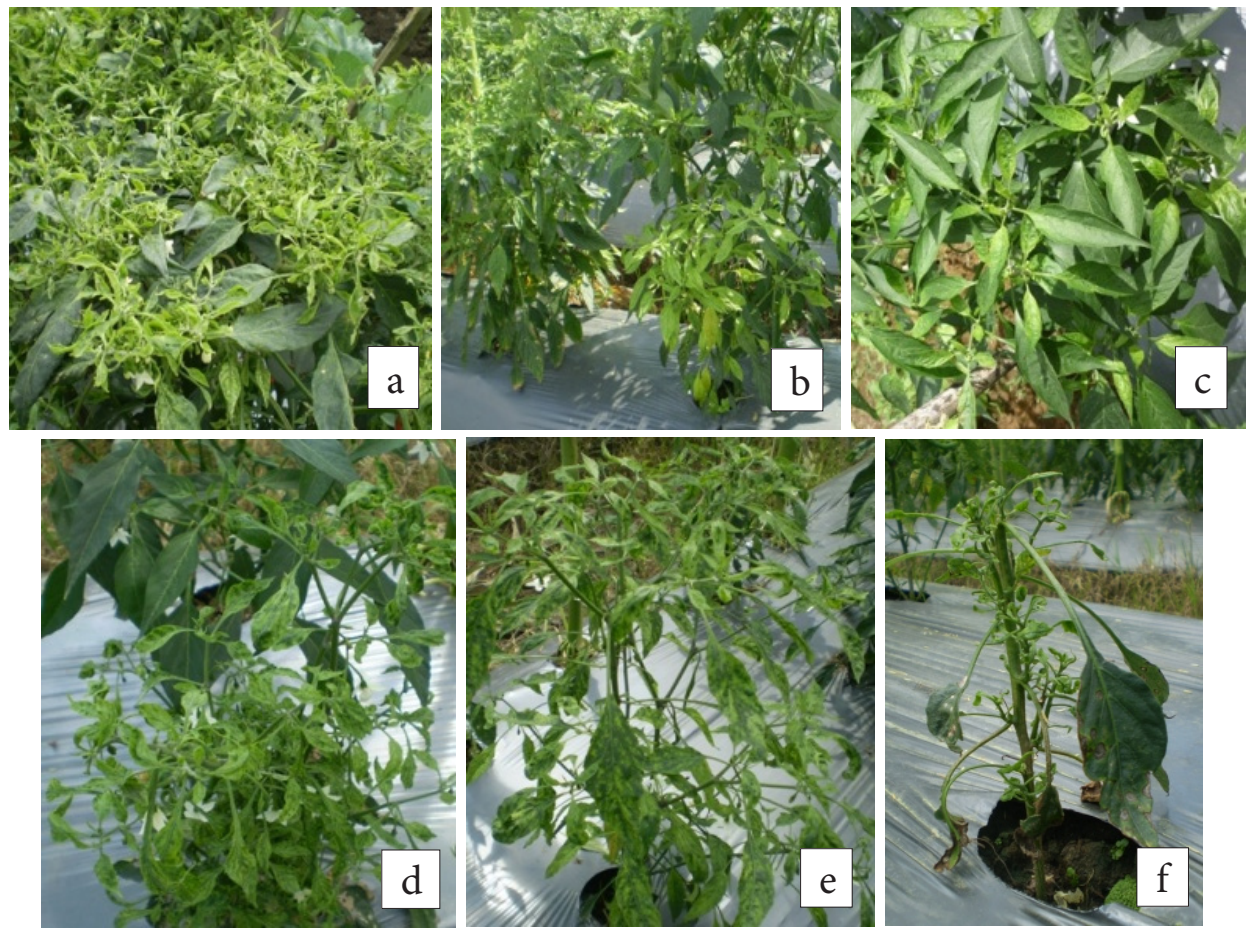

Gambar 1 Gejala infeksi virus pada tanaman cabai di Rejang Lebong; a, mosaik pada daun muda; b, daun menguning sistemik dan kerdil; c, mosaik dan keriting pada daun muda; $\mathrm{d}$, mosaik dan belang; e, belang hijau gelap di sekitar tulang daun; f, penyempitan tulang daun.

Tabel 1 Kejadian penyakit CMV dan ChiVMV pada tanaman cabai di Kabupaten Rejang Lebong berdasarkan hasil deteksi dengan DAS-ELISA

\begin{tabular}{lccc}
\hline Lokasi & \multicolumn{3}{c}{ Kejadian penyakit $(\%)^{*}$} \\
\cline { 2 - 4 } survei & CMV & ChiVMV & CMV + ChiVMV \\
\hline AMA 1 & $0(0)$ & $4 / 7(57.14)$ & $2 / 7(28.57)$ \\
AMA 2 & $0(0)$ & $4 / 8(50)$ & $4 / 8(50)$ \\
MJR 3 & $0(0)$ & $3 / 6(50)$ & $0(0)$ \\
MJR 4 & $0(0)$ & $4 / 5(80)$ & $1 / 5(20)$ \\
MJR 5 & $1 / 5(20)$ & $3 / 5(60)$ & $0(0)$
\end{tabular}

AMA: Air Meles Atas dan MJR: Mojorejo

*adalah perbandingan antara jumlah sampel tanaman yang bereaksi positif pada DAS-ELISA dan jumlah total tanaman yang diuji

\section{Koleksi dan Identifikasi Serangga}

Hanya satu jenis serangga yang berhasil dikoleksi dari lokasi pengamatan, yaitu Aphis gossypii baik nimfa maupun serangga dewasa.

\section{PEMBAHASAN}

Gejala akibat infeksi virus pada tanaman cabai sangat beragam dan infeksi tidak hanya terjadi karena satu jenis virus. Variasi gejala tersebut dipengaruhi oleh beberapa faktor, diantaranya umur tanaman, kultivar, genotipe tanaman, dan fase pertumbuhan tanaman. Faktor lain yang juga mempengaruhi munculnya gejala ialah kesuburan tanah, dan kondisi iklim.

Infeksi CMV sering kali terjadi bersamaan dengan infeksi ChiVMV. Tanaman yang terinfeksi ganda CMV dan ChiVMV mengalami gejala belang dan mosaik yang berat dan sistemik, serta malformasi daun. Hal ini sejalan dengan penelitian Subekti et al. (2006) bahwa tanaman cabai yang terinfeksi ganda CMV dan ChiVMV menunjukkan 
gejala lebih berat daripada infeksi tunggal masing-masing virus. Murphy dan Bowen (2006) menyatakan bahwa infeksi ganda beberapa jenis virus dapat menimbulkan gejala yang lebih berat, atau sebaliknya. Pada saat dua virus menginfeksi bersama-sama, gejala yang muncul dapat disebabkan hanya oleh satu jenis virus dan gejala virus lainnya tidak muncul. Ketika infeksi campuran beberapa jenis virus menimbulkan gejala yang lebih berat maka kedua jenis virus ini disebut sinergis. Berdasarkan pengamatan jenis gejala yang muncul di lapangan, interaksi CMV dan ChiVMV tidak dapat diketahui apakah bersifat sinergis atau interferensi karena ada kemungkinan tanaman cabai tersebut juga terinfeksi oleh jenis virus lainnya.

Kejadian penyakit ChiVMV secara tunggal selalu ditemukan di setiap lokasi pengamatan, sedangkan infeksi CMV secara tunggal hanya ditemukan di 1 lokasi pengamatan. Hal ini menunjukkan bahwa ChiVMV pada cabai di Kabupaten Rejang Lebong tersebar lebih luas dengan kejadian penyakit yang lebih tinggi daripada CMV. Berdasarkan hasil deteksi serologi dengan DAS-ELISA, daun cabai yang terinfeksi ganda oleh kedua virus ini menunjukkan nilai absorban ChiVMV secara umum lebih tinggi daripada CMV. Hasil tersebut sejalan dengan yang dilaporkan Subekti et al. (2006) bahwa pada saat CMV dan ChiVMV diinokulasikan bersama pada tanaman cabai ternyata konsentrasi ChiVMV selalu lebih tinggi daripada CMV. Titer virus dalam jaringan tanaman berkaitan dengan kemampuan virus untuk memanfaatkan tanaman inang dalam proses replikasi dan translokasi. Latifah et al. (2008) melaporkan bahwa konsentrasi ChiVMV selalu lebih tinggi daripada CMV bahkan bila ChiVMV telah menginfeksi lebih dahulu dan sudah bereplikasi di dalam jaringan maka terjadi penekanan pada perkembangan dan pergerakan CMV.

Pola tanam berpengaruh terhadap kejadian penyakit, sehingga salah satu cara mengurangi kejadian penyakit adalah dengan penanaman secara tumpang sari misalnya cabai dengan jagung, atau menghindari menanam tanaman dengan kekerabatan yang dekat secara bersamaan. Di lokasi pengambilan sampel, penanaman cabai dilakukan dengan tumpang sari dan mulsa plastik, namun kejadian infeksi virus masih tinggi. Hal tersebut dikarenakan tumpang sari dan rotasi tanaman dilakukan dengan tanaman yang berkerabat dekat atau tanaman lain yang juga dapat menjadi inang virus, antara lain cabai ditanam secara tumpang sari dengan tomat dan rotasi tanam dengan mentimun.

Faktor lain yang berkontribusi terhadap kejadian penyakit adalah keberadaan serangga vektor di lapangan. Ada satu jenis serangga yang berhasil diidentifikasi dari pertanaman cabai di lapangan, yaitu $A$. gossypii. Serangga ini merupakan salah satu vektor CMV dan ChiVMV. A. gossypii menularkan CMV dan ChiVMV secara non persisten (Palukaitis et. al. 1992; CABI 2005). Seekor kutudaun mendapatkan virus saat makan pada tanaman terinfeksi hanya dalam beberapa detik. Kutudaun dapat segera menularkan virus tersebut ke tanaman lainnya dan kemudian kehilangan virus tersebut saat aktivitas makan. Virus secara umum dapat bertahan pada kutudaun tidak lebih dari satu jam. Berdasarkan pengamatan di lapangan, populasi kutudaun pada tanaman generatif umumnya adalah kutudaun dewasa, dan sebagian besar bersayap. Kondisi tersebut diduga menyebabkan semakin cepatnya penyebaran virus di lapangan.

Hasil penelitian ini membuktikan bahwa infeksi CMV dan ChiVMV pada lahan pertanaman cabai di Kabupaten Rejang Lebong relatif tinggi, dengan frekuensi infeksi ChiVMV lebih tinggi dibandingkan CMV. Sebaran penyakit oleh virus pada tanaman cabai sudah cukup luas dan tentunya akan berdampak pada produktivitas cabai di Rejang Lebong.

\section{UCAPAN TERIMA KASIH}

Penelitian didanai DIPA Universitas Bengkulu tahun 2011. Penulis mengucapkan terima kasih kepada Ir. Yoyo Sulyo, MS. 
dan Erniawati Diningsih, M.Si. dari Balai Penelitian Tanaman Hias, Segunung, Jawa Barat atas bantuan mendeteksi virus.

\section{DAFTAR PUSTAKA}

Agrios, GN. 2005. Plant Pathology. Ed ke-5. San Diego (US): Academic Press.

[AVRDC] Asian Vegetable Research and Development Center. 2003. AVRDC Progress Report 2002. Tainan (TW): Shanhua.

[BPS] Badan Pusat Statistik. 2009. Luas panen, produksi dan produktivitas cabai. http://www.bps.go.id/. [diakses 15 Maret 2011].

[CABI] Centre in Agricultural and Biological Institute. 2005. Chilli veinal mottle virus. Crop Protection Compendium [CD-ROM]. London (UK): CABI.

Cropscience. 2008. Pedoman pengenalan dan pengendalian penyakit virus pada cabai. http://ditlin.hortikultura.deptan.go.id. [diakses 16 Maret 2011].

Duriat AS. 1996. Cabai merah: komoditas, prospek dan andalan. Di dalam: Duriat AS, Hadisoeganda AWW, Soetiarso TA, Prabaningrum L, editor. Teknologi Produksi Cabai Merah. Lembang (ID): Balai Penelitian Tanaman Sayuran.

Godin C, Boivin G. 2002. Field Identification Guide to Aphids in Quebec Vegetable Crops. Canada (AE): Agriculture and Agri-Food Canada.

Latifah, Hidayat SH, Sujiprihati S. 2008. Metode penapisan cabai (Capsicum annuum) untuk ketahanan terhadap
Chilli veinal mottle virus (ChiVMV) dan Cucumber mosaic virus (CMV). J HPT Tropika. 8(2):146-153.

Martin JH. 1983. The identification of common aphid pest of tropical agriculture. Trop Pest Manag. 29(4):395-411. doi: 10.1080/09670878309370834.

Muphy JF, Bowen KL. 2006. Synergistic disease in pepper caused by the mixed infection of Cucumber mosaic virus and pepper mottle virus. Phytopathology. 96(3):240-247. doi: 10.1094/PHYTO-96-0240.

Palukaitis P, Roossinck MJ, Dietzgen RG, Francki RIB. 1992. Cucumber mosaic virus. Adv Virus Res. 41:281-384. doi: 10.1016/S0065-3527(08)60039-1.

Subekti D, Hidayat SH, Nurhayati E, Sujiprihati S. 2006. Infeksi cucumber mosaic virus dan chili veinal mottle virus terhadap pertumbuhan dan hasil tanaman cabai. Hayati. 13(2):53-57.

Sudiono, Yasin N, Hidayat SH, Hidayat P. 2005. Penyebaran dan deteksi molekuler virus gemini penyebab penyakit kuning pada tanaman cabai di Sumatera. J HPT Tropika. 5(2):113-721.

Sutrawati, M. 2010. Deteksi serologi virus penyebab penyakit mosaik pada tanaman cabai dengan DAS-ELISA. Jurnal Agriculture. 17(1):626-630.

Taufik M, Astuti AP, Hidayat SH. 2005. Survei infeksi Cucumber mosaic virus dan Chilli veinal mottle virus pada tanaman cabai dan seleksi ketahanan beberapa kultivar cabai. Agrikultura. 16:146-152. 